\title{
Epiphytic Diatom Communities on Sub-Fossil Leaves of Posidonia oceanica Delile in the Graeco-Roman Harbor of Neapolis: A Tool to Explore the Past
}

\author{
Paola Cennamo ${ }^{*}$, Paolo Caputo ${ }^{2}$, Mario De Stefano ${ }^{3}$, Elda Russo Ermolli4 ${ }^{4,5}$, \\ Maria Rosaria Barone Lumaga ${ }^{2}$ \\ ${ }^{1}$ Facoltà di Lettere, Università degli Studi Suor Orsola Benincasa, Naples, Italy \\ 2Dipartimento di Biologia, Orto Botanico, Università di Napoli "Federico II", Naples, Italy \\ ${ }^{3}$ Dipartimento di Scienze e Tecnologie Ambientali, Biologiche e Farmaceutiche, Seconda Università di Napoli, \\ Caserta, Italy \\ ${ }^{4}$ Dipartimento di Scienze della Terra, dell'Ambiente e delle Risorse (DISTAR), Università di Napoli Federico II, \\ Naples, Italy. \\ ${ }^{5}$ Département de Préhistoire, Muséum National d'Histoire Naturelle, Centre National de la Recherche \\ Scientifique, Paris, France \\ Email: *paola.cennamo@unisob.na.it
}

Received 25 December 2013; revised 1 February 2014; accepted 20 February 2014

Copyright (C) 2014 by authors and Scientific Research Publishing Inc.

This work is licensed under the Creative Commons Attribution International License (CC BY).

http://creativecommons.org/licenses/by/4.0/

(c) (i) Open Access

\section{Abstract}

The Graeco-Roman harbor of Neapolis (Naples, Italy), chronologically constrained between the late 4th century $B C$ and the 6th century $A D$, offers a unique sight on relationship between past and present into the history of the marine biodiversity. In fact, the digs expose fossil leaf of Posidonia oceanica with epiphytic communities of microorganisms. Posidonia oceanica is a seagrass endemic to the Mediterranean that forms large meadows whose remains can persist in the sediment for thousands of years. In this communication, we report results of analyses carried out using both molecular and morphological techniques on sub-fossil leaves of $P$. oceanica and their associated epiphytic communities.

\section{Keywords}

Posidonia oceanica; Epiphytic Communities; Ancient DNA

\footnotetext{
${ }^{*}$ Corresponding author.
}

How to cite this paper: Cennamo, P., et al. (2014) Epiphytic Diatom Communities on Sub-Fossil Leaves of Posidonia oceanica Delile in the Graeco-Roman Harbor of Neapolis: A Tool to Explore the Past. American Journal of Plant Sciences, 5, 549-553. http://dx.doi.org/10.4236/ajps.2014.55070 


\section{Introduction}

Posidonia oceanica (Delile) has been present in the Mediterranean Sea since the Miocene. During the last glaciation, it survived in refugia from which it re-colonized the basin [1] [2]. It presently grows along the coast of the Eastern and Western basins into which the Mediterranean is divided, developing associated communities characterized by conspicuous species diversity [3] Several studies on the distribution and conservation of this plant by employing morphological or molecular data have been carried out, including one regarding ancient Posidonia plants presented in the marine sediment in the bay of Naples dated $300 \mathrm{yr}$ ago [4]. The Graeco-Roman harbor of Neapolis was discovered in 2004 in the area of Piazza Municipio (Naples, Italy), about $500 \mathrm{~m}$ from inland as compared to the modern docks of Naples [5]. The excavations brought to light huge amounts of stratigraphic and archaeological data which allowed the harbor sedimentary record to be chronologically constrained between the late 4th century BC and the 6th century AD [5]. The infilling succession is made up of marine, transitional and continental deposits overlaying a volcanic bedrock consisting of tuffs and pyroclastics of the Neapolitan Yellow Tuff [6] [7]. The most representative sections exposed in the digs were sampled for sedimentological, pa- leoenvironmental and paleobotanical analyses [6]-[8]. In particular, a 7-m thick succession, representing the in- filling of a protected inlet in the ancient harbor, was brought to light and sampled for pollen analysis [17]. This site represents an important archive of marine eukaryotic biodiversity. As such, the Greco-Roman harbor offers a unique opportunity to study sub-fossil samples of Posidonia oceanica and to analyze the remains of the epi- phytic communities of microorganisms. No archeobotanical studies are available analyzing aquatic plants re- mains together with their associated epiphytes on both morphological and molecular standpoints. Morphological analysis of botanical remains is comparatively simple since an extensive reference dataset is available to help interpretation, but it also has some limitations, in this case mainly related to plant material degradation. In the present work, we analyze sub-fossil leaves of $P$. oceanica from the Graeco-Roman harbor of Neapolis with their associated epiphytic communities, using both molecular and morphological techniques.

\section{Material and Methods}

Samples collected from the lagoon layers (Figure 1(a)) of the Graeco-Roman harbor dated to the 5th century AD, were compared with leaves of Posidonia oceanica obtained from herbaria or directly collected on shores and dried (sources are listed in Table 1). The samples were dropped in ethanol for 3 - 4 days at room temperature and dehydrated in an ethanol series, critical point dried and sputter-coated with approximately $30 \mathrm{~nm}$ of gold. Specimens were examined using a FEI-Quantas 200 ESEM at an accelerating voltage of $20 \mathrm{kV}$. The DNA region chosen for molecular analyses was the 18S nuclear DNA. Total genomic DNA was isolated from approximately $100 \mathrm{mg}$ of sub-fossil leaves following a modified CTAB procedure [4]. Molecular markers were amplified using primers from literature [9]. Complete sequences of each PCR product were obtained, aligned, and inspected with the AB DNA Sequencing Analysis software ver. 5.2 (Applied Biosystems, Life Technologies), Sequence Navigator ver. 1.0.1 software (ABI Prism, Perkin Elmer) and BioEdit ver. 7.0.9.0 software [10].

Table 1. List of the species Posidonia oceanica obtained from herbaria or directly collected.

\begin{tabular}{cc} 
Taxon & Origin \\
\hline P. oceanica & P6.1us7282e \\
Naples (Italy) 2012 \\
P. oceanica & Linosa (Italy) 1906 \\
P.oceanica & Ischia (Italy) 2012 \\
P. oceanica & Rodi (Greece) 1925 \\
P. oceanica & Tripoli (Libya) 1919 \\
P. oceanica & Bengasi 1921 \\
P. oceanica & Bengasi (Libya) 1919 \\
P. oceanica & Elba Island (Italy) 1981 \\
\hline
\end{tabular}




\section{Results and Discussion}

Posidonia oceanica samples have been identified on the grounds of macro- and micro-morphological characters. All the studied leaves (sub-fossil and reference samples) are yellow-brownish, about $0.8-1.2 \mathrm{~cm}$ wide and show numerous veins. The sub-fossil and herbarium samples are fragments $3-4 \mathrm{~cm}$ long. At the micro-morphological level, the epidermis is covered by a smooth cuticle, lacks stomata, shows rectangular pavement cells with straight cell walls and perpendicular to oblique transverse cell walls (Figures 1(b)-(e)). Fibre strips are visible in samples where the epidermis is damaged (Figure $\mathbf{1}(\mathrm{f})$ ). Hyphae and epiphytic diatoms are clearly visible on the sub-fossil leaves, whereas members of the bacterial community, usually represented by Marinomonas posi- donica [11] and other similar species, are less frequent and more difficult to observe. On the contrary, these bacteria are widely visible on the references samples collected in nature or obtained from herbaria (Figure 1(e)).

Diverse epiphytic diatoms are evident on the sub-fossil leaves (Figures 2 (a)-(f)). They are all recent benthic species [12]-[15] and namely: the adnate species Cocconeis stauroneiformis (Rabenhorst) Okuno (Figure 2(a)) and Amphora cfr helenensis Giffen (Figure 2(b)), individuals of Nitchia cfr punctata Grunow (Figures 2(c)-(e)) and a broken frustule of the motile species Navicula directa (W. Smith) Ralfs (Figure 2(f)). All these species are commonly present on living $P$. oceanica plants which, however, usually show a much complex epiphytic diatom community, often including hundreds of species [16].

The $18 \mathrm{~S}$ sequences from the subfossil specimens were $100 \%$ identical to those of $P$. oceanica AY491942.

The vertical extent of the P. oceanica remains in the lagoon layers (Figure 1(a)) is indicative of matte formations that usually occurs when the meadow is buried by an amass of sediments in a relatively short time. This support the hypothesis that the sedimentary infilling and final closure of the bay brought about the decline in

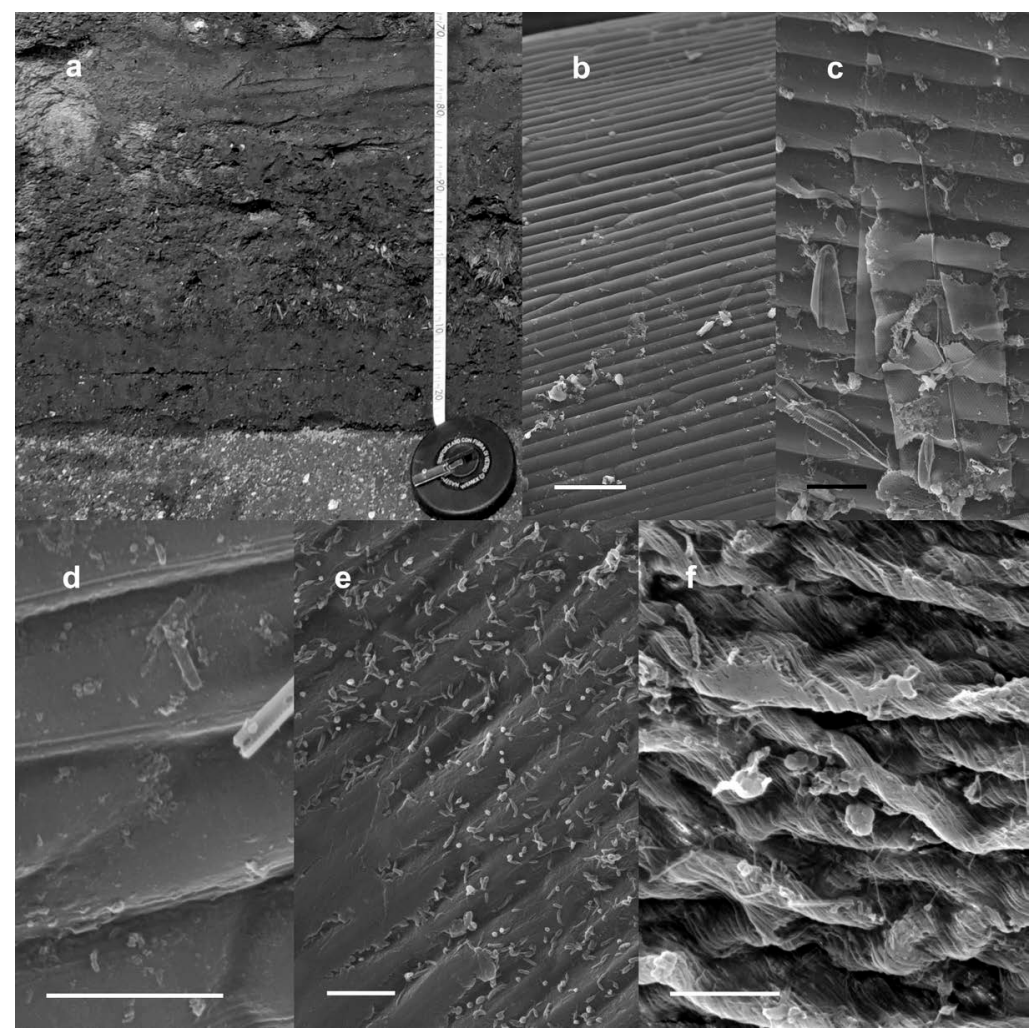

Figure 1. a: Detail of the section exposed in the Piazza Municipio (PM) dig. b: SEM of Posidonia oceanica leaf surface (PM). c: SEM detail of $P$. oceanica leaf (PM) surface showing epiphytic hyphae and diatoms. d: SEM detail of $P$. oceanica leaf (PM) surface showing scanty presence of epiphytic bacteria. e: SEM of $P$. oceanica leaf surface (sample collected at Linosa island, Sicily, Italy) showing considerable presence of Marinomonas posidonica. f. Fibres on P. oceanica (PM) samples. Scale bars b $50 \mu \mathrm{m}, \mathrm{c}$ - f $10 \mu \mathrm{m}$. 


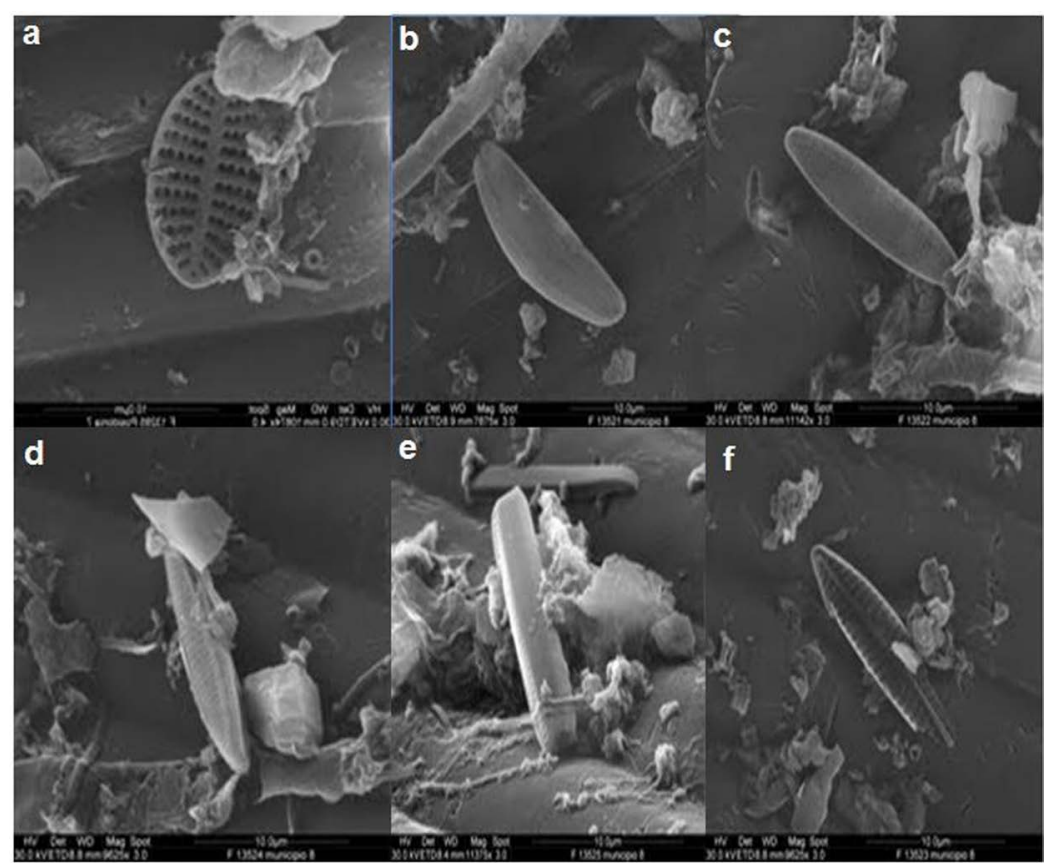

Figure 2. a: Cocconeis stauroneiformis. b: Amphora cfr helenensis. c-e: Nitchia cfr punctata. f: broken frustule of motile species Navicula directa.

harbor activities until their complete abandonment [17].

\section{Conclusion}

The Graeco-Roman harbor of Neapolis has an archeological area full of material to be investigated. Studies are in progress to extend our knowledge of the algal biodiversity and understand whether the observation of reduced epiphytic communities on the Posidonia sub-fossil samples is indeed the record of a locally reduced occurrence of diatom and bacteria or it is related to the sedimentary infilling and burial process of matte.

\section{Acknowledgements}

The authors wish to thank the "Soprintendenza Speciale per i Beni Archeologici di Napoli e Pompei" and in particular Dr. Daniela Giampaola, for the opportunity to participate in the study of Neapolis. Besides, the authors thank Claudia Cimmino for SEM preparations. Many thanks are due to the curators of the following herbaria: Roberta Valleriello (NAP), Chiara Nepi (FI), Gianniantonio Domina (PAL).

\section{References}

[1] Pérès, J.M. (1984) La Regression des Herbies a Posidonia oceanica. In: Boudouresque, C.F., de Grissac, A.J., Olivier and J., Eds., International Workshop on Posidonia oceanica Beds, Vol. 1, GIS Posidonie, Marseille, 445-454.

[2] Pérès, J.M. (1985) History of the Mediterranean Biota and the Colonization of the Depths. In: Margalef, R., Ed., Western Mediterranean, Pergamon Press, Oxford, 198-232.

[3] Mazzella, L., Buia, M.C., Gambi, M.C., Lorenti, M., Russo, G.F., Scipione, M.B. and Zupo, V. (1992) Plant-Animal Trophic Relationship in the Posidonia oceanica Ecosystem of the Mediterranean Sea: A Review. In: John, D.M., Howkins, S.J. and Price, J.H., Eds., Plant-Animal Interaction in the Marine Benthos, Clarendon Press, Oxford, 165-187.

[4] Raniello, R. and Procaccini, G. (2004) Ancient DNA in the Seagrass Posidonia oceanica. Marine Ecology Progress Series, 227, 269-273. http://dx.doi.org/10.3354/meps227269

[5] Giampaola, D., Carsana, V., Boetto, G., Bartolini, M., Capretti, C., Galotta, G., Giachi, G., Macchioni, N., Nugari, M.P. and Pizzo, B. (2006) La Scoperta del Porto di Neapolis: Dalla Ricostruzione Topografica allo scavo e al Recupero dei Relitti. Archeologia Marittima Mediterranea, 2, 47-91. 
[6] Amato, L., Carsana, V., Cinque, A., Di Donato, V., Giampaola, D., Guastaferro, C., Irollo, G., Morhange, C., Romano, P., Ruello, M.R. and Russo Ermolli, E. (2009) Ricostruzioni Geoarcheologiche e Morfoevolutive nel Territorio di Napoli (Italia): L’evoluzione Tardo Pleistocenica-Olocenica e le Linee di Riva di Epoca Storica. Méditeranée, 112, 23-31. http://dx.doi.org/10.4000/mediterranee.3045

[7] Carsana, V., Febbraro, S., Giampaola, D., Guastaferro, C., Irollo, G. and Ruello, M.R. (2009) Evoluzione del Paesaggio Costiero tra Parthenope e Neapolis: Una Sintesi Geoarcheologica per L'area Dell'antico Porto. Méditerranée, 112, $15-22$.

[8] Allevato, E., Russo Ermolli, E., Boetto, G. and Di Pasquale, G. (2005) Pollen-Wood Analysis at the Neapolis Harbour Site (1st-3rd Century AD, Southern Italy) and Its Archaeobotanical Implications. Journal of Archaeological Science, 37, 2365-2375. http://dx.doi.org/10.1016/j.jas.2010.04.010

[9] Nickrent, D. and Starr, E.M. (1994) Higt Rates of Nucleotide Substitution in Nuclear Small-Subunit (18S) rDNA from Holoparasitic Flowering Plants. Journal of Molecular Evolution, 39, 62-70. http://dx.doi.org/10.1007/BF00178250

[10] Hall, T.A. (1999) BioEdit: A User-Friendly Biological Sequence Alignment Editor and Analysis Program for Windows 95/98/NT. Nucleic Acids Symposium Series, 41, 95-98.

[11] Lucas-Elío, P., Marco-Noales, E., Espinosa, E., Ordax, M., López, M.M., Garcías-Bonet, N., Marbà, N., Duarte, C.M. and Sanchez-Amat, A. (2011) Marinomonas alcarazii sp. nov., M. rhizomae sp. nov., M. foliarum sp. nov., M. posidonica sp. nov. and M. aquiplantarum sp. nov., Isolated from the Microbiota of the Seagrass Posidonia oceanica. International Journal, 61, 2191-2196.

[12] Mazzella, L. (1983) Studies on the Epiphytic Diatoms of Posidonia oceanica (L.) Delile Leaves. Rapport Commission International Mar Mediterranean, 28, 123-124.

[13] De Stefano, M., Marino, D. and Mazzella, L. (2000) Marine Taxa of Cocconeis on Leaves of Posidonia oceanica, Including a New Species and Two New Varieties. European Journal of Phycology, 35, 225-242. http://dx.doi.org/10.1080/09670260010001735831

[14] De Stefano, M. and Marino, D. (2003) Morphology and Taxonomy of Amphicocconeis. gen. nov. (Achnanthales, Bacillariophyceae, Bacillariophyta) with Considerations on Its Relationship with Other Related Monoraphid Diatom Genera. Europian Journal of Phycoly, 38, 361-370. http://dx.doi.org/10.1080/09670260310001612646

[15] De Stefano, M. and Romero, O.E. (2005) A Survey of Alveolate Species of the Diatom Genus Cocconeis (Ehr.) with Remarks on the New Section Alveolatae. Bibliotheca Diatomologica, 52, 1-133.

[16] De Stefano, M., Romero, O. E. and Totti, C. (2008) A Comparative Study on Cocconeis scutellum Ehr. and Its Varieties (Bacillariophyceae, Bacillariophyta). Botanica Marina, 51, 506-536. http://dx.doi.org/10.1515/BOT.2008.058

[17] Russo Ermolli, E., Romano, P., Ruello, M.R. and Barone Lumaga, M.R. (2014) The Natural and Cultural Landscape of Naples (Southern Italy) during the Graeco-Roman and Late Antique periods. Journal of Archaeological Science, 42, 399-411. http://dx.doi.org/10.1016/j.jas.2013.11.018 